\title{
Extractive activity of Euterpe oleracea Mart. (Acai palm tree) in the Araguari River Valley, Eastern
}

\author{
Amazon \\ João da Luz Freitas, Erick Silva dos Santos, Francisco de Oliveira Cruz Junior, Adriano \\ Castelo dos Santos (Corresponding Author) \\ Dept. of Botany, Forest Management Laboratory, Instituto de Pesquisas Científicas e \\ Tecnológicas do Estado do Amapá, Macapá, Amapá, Brazil
}

Received: Oct. 21, 2019

Accepted: Nov. 17, 2019

Published: Dec. 8, 2019

doi:10.5296/jas.v8i2.15679

URL: https://doi.org/10.5296/jas.v8i2.15679

\begin{abstract}
The acai palm tree is a species of multiple use and of great importance for the Amazonian economy and riverside families. The high appreciation of the acai berry in the national and international markets contributes to the search for new producing areas and the reduction of repressed demand. This research aimed to identify the knowledge of the riverside families about the acai berry extraction activity in the Araguari river valley. The study was between the municipalities of Ferreira Gomes and Cutias, in an extension of 80 kilometers. The properties were sampled according to the following criteria: i) presence of natural acai massifs; ii) acceptance of the research by the interviewee and iii) permission to implement sample plots. Data were obtained through a form and interviews with structured questions. Non-probabilistic sampling $(\mathrm{n}=13$ ) was used to select local extractivists who hold acai areas. The field research with extractivists allowed us to infer that the period of high fruit production extends from March to June. The use of byproducts of the acai is little expressive. Although livestock is the most expressive activity in the region, others stand out: fishing, agriculture and extractivism. The commercial production of acai fruit is destined to the municipality of Cutias and most native acai owners have significant interest in the management of this species.
\end{abstract}

Keywords: vegetal extractivism, native acai palm, floodplain, ethno-knowledge

\section{Introduction}

According to FAO (2014), it is estimated that 750 million people worldwide depend directly on forest resources for their livelihoods and survival. New evidence continues to point to an increase in world hunger in recent years following a prolonged decline. It is estimated that 
821 million people, approximately one in nine people in the world are malnourished (FAO, 2018). The extractive activity of native non-timber forest products has great relevance for subsistence and income generation for traditional populations, such as Amazonian riverine populations (IBGE, 2017).

The increasing popularization and valorization of "acai berry" in the national and international markets has generated growing demand for its byproducts, such as fruit pulp, energy, freeze-dried products, among others, boosting regional economies and contributing to the income generation of extractive populations from the Amazon. Acai juice is the most consumed beverage in the Amazon region, where individual consumption can reach one liter per day, presenting several potential health benefits to consumers, mainly due to its high concentrations of polyphenols and anthocyanins (Bichara \& Rogez, 2011). Due to its composition and consequent benefits to human health is considered a functional food. The acai fruit pulp has been used in the food industry as natural pigment, cosmetic, pharmaceutical, oil extraction, candy, gelatin capsules, powders and teas. In addition, acai seeds have been used in the manufacture of biojewels (Oliveira \& Schwartz, 2018).

The palm tree Euterpe oleracea Mart. (acai palm tree), family Arecaceae (Tropicos, 2018), is a native species of the Amazon River basin, grows in groups of up to 20 stems that together can produce $120 \mathrm{~kg}$ of fruits per year or even more under forest management system (Oliveira \& Schwartz, 2018). It is characterized by being a fast growing palm tree, with the highest stems reaching 20 to 25 meters. The root system is called a pneumatophore, which allows it to adapt to seasonal flooding. The flowers are unisexual grouped in composite panicles, being from yellow brown to purple and flowering occurs throughout the year with peak between February and July (Amsellem-Laufer, 2015). It forms large spontaneous populations, concentrated in the northeast of Pará, Amapá, Maranhão, Mato Grosso, and Tocantins.

In the Amazon rainforest, the acai palm tree stands out for being the most productive, in both fruits and other plant derivatives. The national demand for acai has been growing over the years and can be attributed, among other factors, to its nutritional properties and its caloric value, because the fruit is considered a food rich in protein, fiber, vitamin E, lipids and minerals, as manganese, copper, boron and chromium (Araujo \& Navegante-Alves, 2015; Neves et al., 2015).

Research conducted in the Amazon with E. oleracea has shown the importance of the species for the populations that inhabit the floodplains of the Amazon estuary (Calzavara, 1972; Freitas et al., 2010; Nogueira \& Homma, 2014; Cruz Junior, 2016; Silva Junior et al., 2019). Therefore, the objective of the research was to identify the knowledge of the riverside families about the acai berry extraction activity in the Araguari river valley. 


\section{MInstitute ${ }^{\text {Macrothink }}$}

\section{Materials and Methods}

\subsection{Study Area}

The study was carried out in the Araguari River Valley, Araguari River Basin, covering the municipalities of Ferreira Gomes and Cutias, with an extension of $80 \mathrm{~km}$ from the Tancredo Neves Bridge (front of Ferreira Gomes administrative headquarters) to the Cutias administrative headquarters (Figure 1). The two municipalities are located in the Central and Eastern regions of the state of Amapá, respectively, being Ferreira Gomes in the geographic coordinates $\mathrm{N} 00^{\circ} 51.38$ 'and $\mathrm{W} 051^{\circ} 11.74$ ' and Cutias $\mathrm{N} 01^{\circ} 0.76$ 'and $\mathrm{W} 050^{\circ} 48.66$ '.

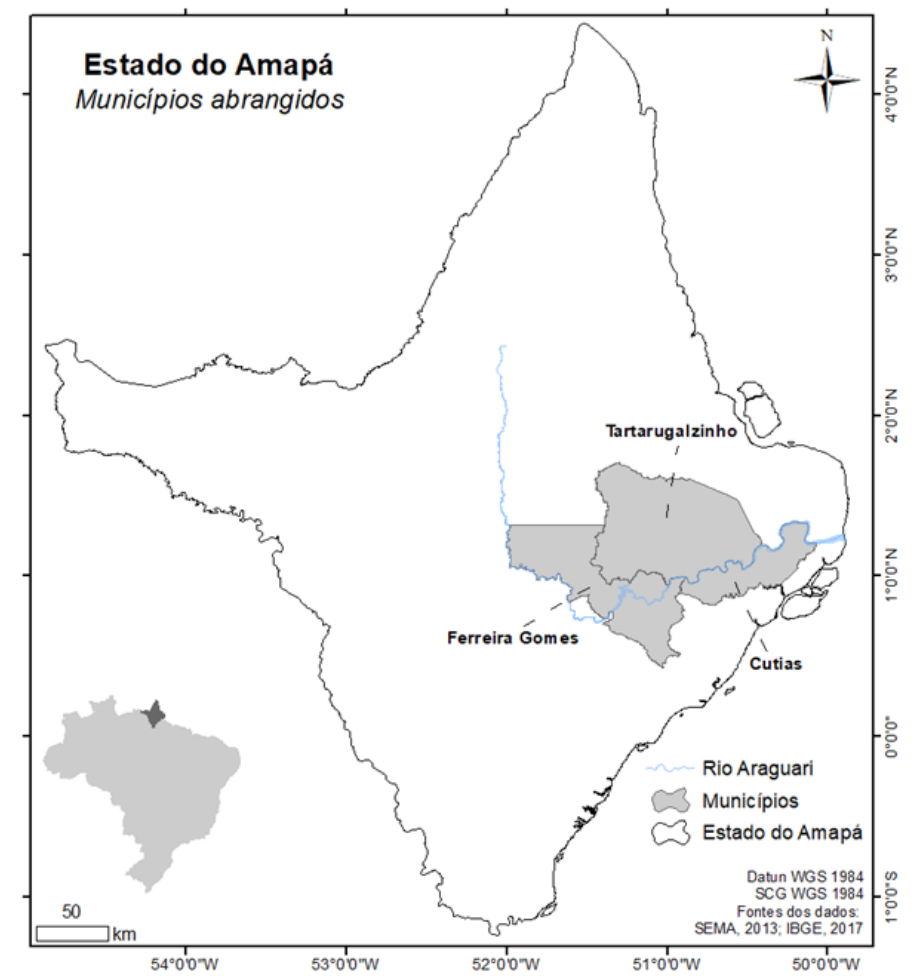

Figure 1. Location of the study area

The vegetation of the Araguari River Valley region is composed of terra firme forests, floodplain, igapó and natural fields. They reach maximum temperatures of $32.6{ }^{\circ} \mathrm{C}$ and minimum of $20^{\circ} \mathrm{C}$. The region's climate is tropical rainy type Am, according to the Köppen classification (Alvares et al., 2013). The region includes important power generation projects, such as Coaracy Nunes Hydroelectric Plants, Ferreira Gomes and Cachoeira Caldeirão. The vegetal extractivism is an important economic and social function in the Araguari River, which, associated with artisanal fishing, decisively influences the subsistence of riverside populations along the river. The acai palm tree makes up the landscape and the backyards along the Araguari River, as observed in Figure 2. 


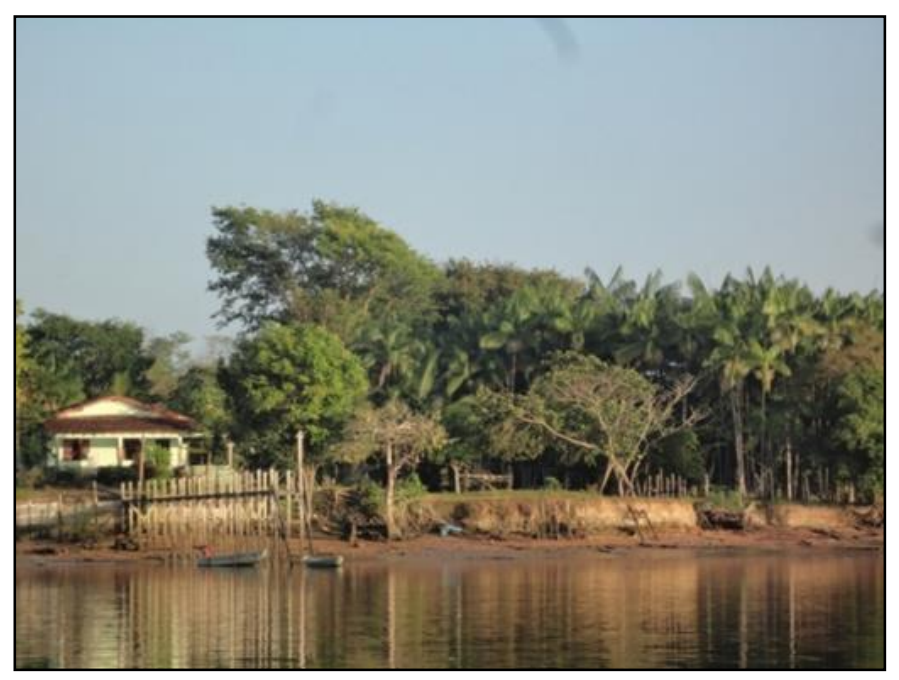

Figure 2. The acai berry is an important component in the diet of riverside families in the Araguari River valley

Source: Francisco Oliveira

\subsection{Occurrence of Native Acai Palm Tree}

The species E. oleracea strongly composes the phytophysiognomy of the studied area, but for the research, the properties were sampled according to the criteria as: i) presence of massifs of natural acai; ii) acceptance of the survey by the interviewee; iii) permission for the implementation of the plots; iv) and collection of qualitative and quantitative data and geographical coordinates of the clumps of acai palm tree (Figure 3).

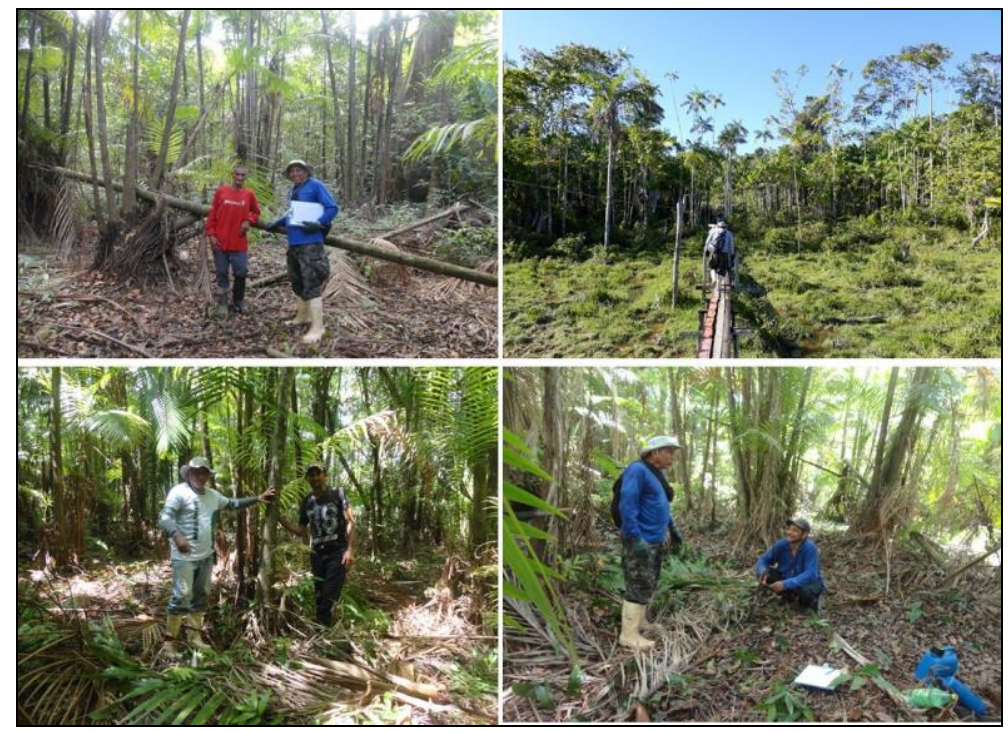

Figure 3. Owners, researchers and plots established in the Araguari Valley Source: João Freitas

\subsection{Data Collect}

A form was prepared for the interviews with structured questions, aiming to identify the 


\section{Macrothink

knowledge of the native acai berry owners about the most varied aspects of the economic and ethnobiological activity of acai extractivism: (i) period of fruit production; ii) silvicultural treatments; iii) spacing, density of acai palm trees, number of stems and forms of continued production; iv) area with acai; (v) disease and animal occurrences in native acai palm tree; vi) uses and parts of the acai palm tree; vii) activities performed by the owners; viii) places for marketing the acai fruit; and ix) rural credit and extension.

We tried to identify which months of the year in which there are higher and lower yields of acai fruit, i.e., the period of harvest and off-season of the species in the area studied, making a brief relationship between the indications of native acai owners with the rainfall of the year 2018 .

As a method of guiding the implementation of the plots, the sense was followed by Ferreira Gomes to Cutias (Figure 1), which identified the first property with the characteristics for the research, i.e., possessing natural acai massifs, and thus adopted The procedure of spontaneous indication of the interviewee to reach the next property, until the last property near the municipality of Cutias (urban perimeter).

Non-probabilistic sampling $(\mathrm{n}=13)$ was used to select local extractivists who hold acai areas. Thirteen native acai plantation owners were interviewed. The interviews were conducted at the headquarters of their properties and/or in their acai area according to Chambers (1994).

\subsection{Data Analysis}

The data collected and recorded in the field forms were organized and systematized. They were tabulated and synthesized using the Microsoft Office Excel 2016 program to form a database. The data regarding the informants were organized in tables and graphs elaborated in the statistical software R (Core Development Core Team) and Microsoft Excel 2016.

\section{Results and Discussion}

\subsection{Fruit Production Period}

According to the owners, the fruit production phase occurs between January and August, coinciding with the period of greatest rainfall in the region. Peak production occurs in April and May, with an indication of $79 \%$ of respondents (Figure 4). 


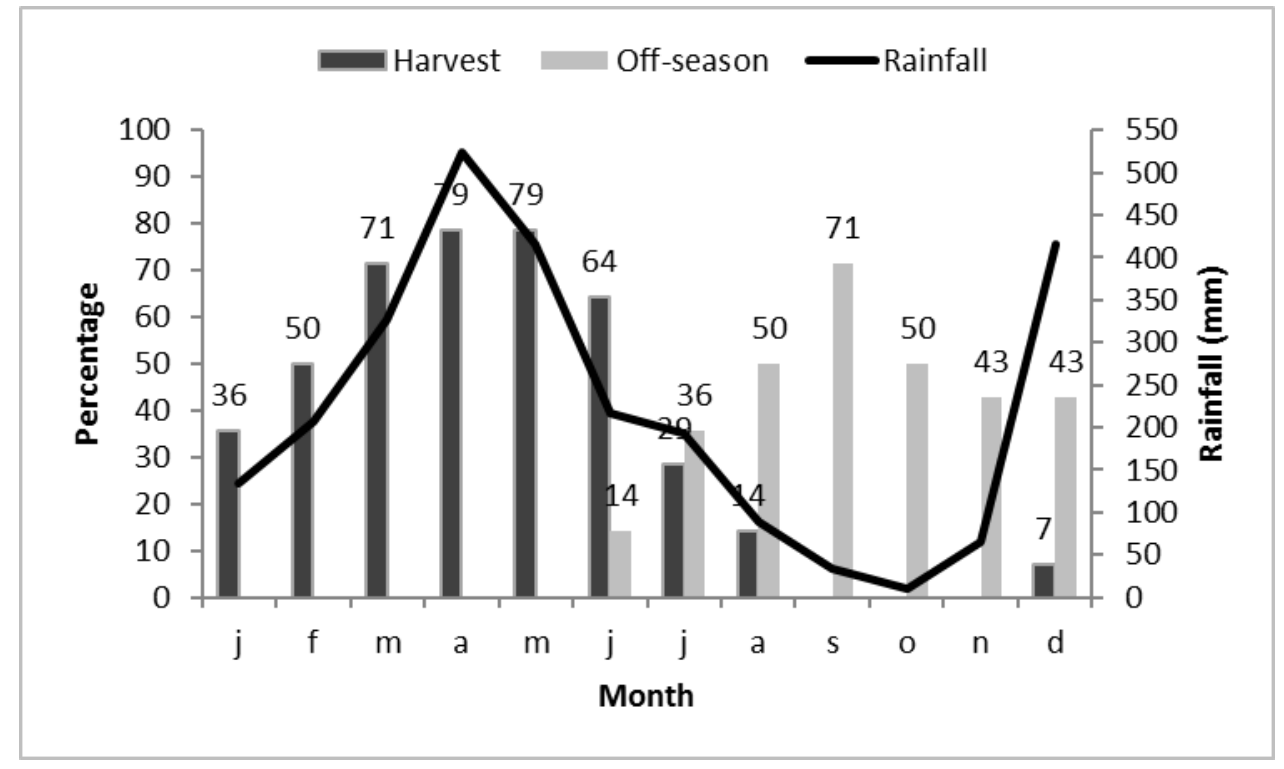

Figure 4. Perception of owners native acai on the harvest and off-season of the acai fruit along the Araguari River

Source: Field Research (2018)

The off-season, marked by the sharp decline in fruit production, occurs from June to December, peaking in September, according to $71 \%$ of owners interviewed. This phase coincides with the period of lowest rainfall in the state of Amapá (Figure 4).

Studies conducted in the Amazon with reproductive events of E. oleracea demonstrate that the fruiting of the species occurs with greater intensity during the period of greatest rainfall (Freitas et al., 2010; Cruz Junior, 2016). In field research in the São Tomé community in the Araguari valley, Santos et al. (2015) also obtained similar results in relation to the period of fruit production of the acai berry, corroborating the results of this study.

\subsection{Silvicultural Tract}

Silvicultural treatments such as mowing, weeding and thinning are important initial actions in the formation and conduction of productive native acai areas. Thus, the survey found that $62 \%$ of native acai owners do not exert any silvicultural tract action in their acai areas, and only $38 \%$ perform mowing activity.

The excessive number of stems and/or regenerating individuals in a clump reduces the fruit production of the species. Thus, the management of native acai is fundamental for the good development of the productive cycle of the species, allowing increase of production and fruit productivity (Queiroz et al., 2015; Santos et al., 2018).

The management of acai pam trees for the Amazon region becomes important because it enables and establishes exploratory norms according to local conditions, aiming to replace the traditional deforestation that damages the future of the local forest economy (Quaresma; Cunha, 2012; Higman et al., 2015). 


\subsection{Spacing, Density and Number of Stems}

We tried to identify with the native acai owners if the spacing between the clumps has influence on the fruit production of the species. In this sense, $100 \%$ revealed to have knowledge that the spacing between clumps in native acai palm tree when performed according to forest management techniques, promotes greater fruit production (Figure 5), reporting that: i) space dispute decreases production; ii) produces faster; iii) the bunches are larger; iv) clumps very close influence the growth of the plant/with clumps too close, the palm tree decreases the CAP (tapering of the stem); and v) very close clumps/thin cluster, fruit production decreases.

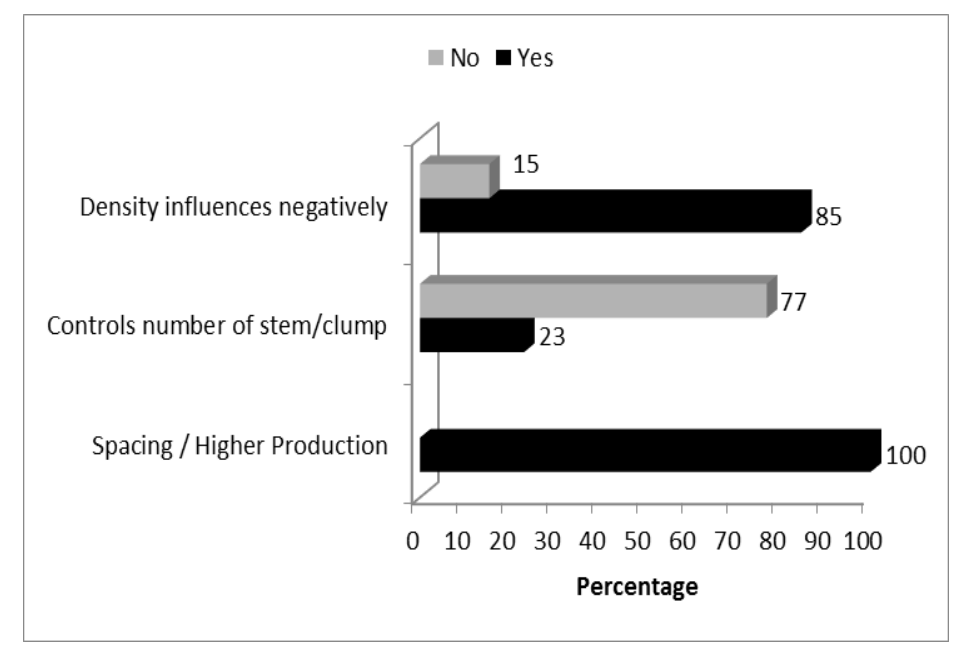

Figure 5. Knowledge of spacing, density of palms and number of stems in the palm clump along the Araguari River

Source: Field Research (2018)

The practice of controlling the number of stems per clump in the native acai was another question to be asked to the owners. Only $23 \%$ perform clumps thinning in order to control the number of stems and increase fruit production, while $77 \%$ do not control stems in the clump (Figure 5).

Regarding stem spacing in the group, $85 \%$ consider that stem spacing contributes negatively to acai production, while $15 \%$ do not consider that the number of stem influences (Figure 5).

As for the acai berry production techniques, 38\% said they did not know and $62 \%$ knew or had heard of practices, but without practical and / or scientific proof. Management actions that improve the fruit productivity of the species are fundamental to leverage the acai productive chain in the region. It was observed through this research that most owners are unaware of any initiative to use acai management techniques, which highlights the importance and their desire to know the forest management techniques to increase fruit production of acai, food security, family income generation and local development.

However, management techniques must be carried out rigorously and in compliance with federal and local environmental licensing standards, avoiding negative impacts on acai areas 
and biodiversity. Freitas et al. (2015) reported that the current exploitation model practiced by the riverside communities of the Amazon, maintaining an average density of 200 palm trees $\mathrm{ha}^{-1}$, led to a loss of more than $50 \%$ of tree species diversity.

\subsection{Area With Native Acai Palm Tree}

Different sizes of areas with native acai massifs were identified. According to the owners, the average area was 33.7 ha, with the smallest area with 2 ha and the largest with 100 ha. Knowing the area with a strong presence of acai is important for the planning of owners native acai, for the sizing of costs and revenues of the productive activity, as well as the targeting of public-private incentives for productive activity. Santos et al. (2015), in a survey of a community on the Araguari River, reported that most landowners had areas of 30 to 50 ha available to work on the extractive production of forest products, including the acai fruit.

The high appreciation of acai berry in the national and international markets led the market to explore more floodplain areas, implement forest management techniques and introduce in terra firme areas aiming to increase fruit production and productivity and satisfy the demand (Mendes et al., 2012).

\subsection{Occurrence of Diseases and Animals in Native Acai Palm Tree}

The occurrence of pests and diseases is present in all ecosystems, whether natural, artificial or modified. Thus, we tried to identify, with the owners native acai, the knowledge of some disease that attacks the acai tree in their areas, but not all reported knowing this occurrence (Figure 6).

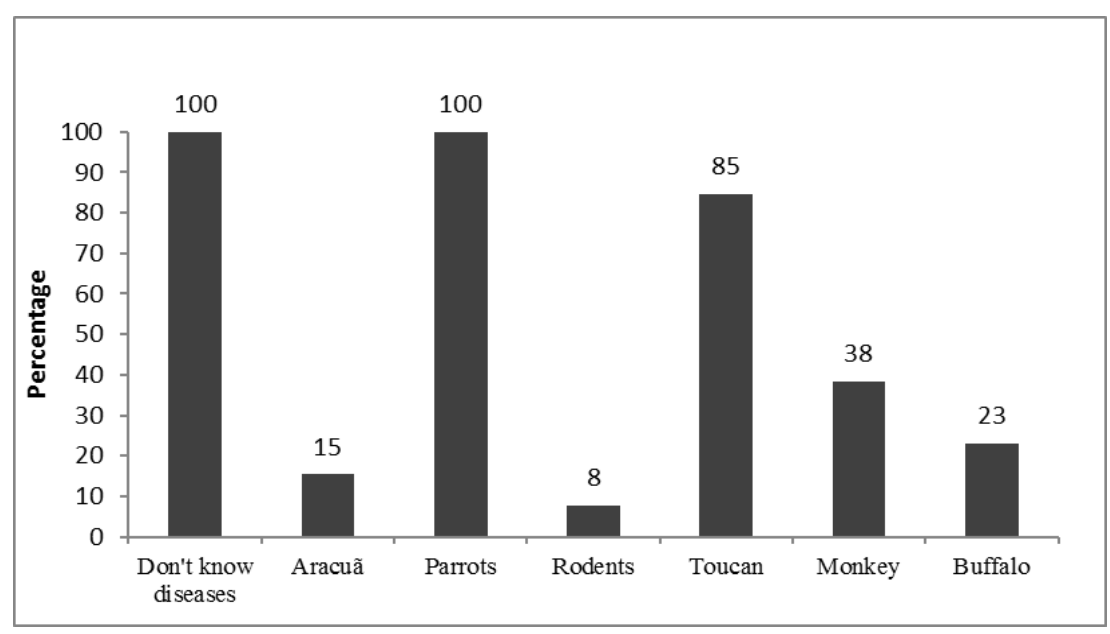

Figure 6. Disease and animal occurrences in native acai palm trees areas

Source: Field Research (2018)

Regarding animal competition in native acai areas, $100 \%$ indicated the parrot group (such as Macaws, Parakeets and Maracanã), 85\% Toucan and 23\% Buffalo (Figure 6). The presence of animals in native acai areas is constant and natural, but during the fruit ripening period, the visitation is more constant and with a larger number of species and individuals. 
From an ecological point of view, the presence of fauna interacting with the acai is important for the balance of the forest ecosystem and for the maintenance and reproduction of the acai. However, the presence of large animals, mainly buffalo, without control and management, invading acai areas, has proved to be a problem in the region for acai extractivists. These animals have been reported to cause environmental impacts in the Araguari Valley region (Silva et al., 2018).

\subsection{Uses of Acai Palm Tree}

It was found that none of the owners interviewed remove the palm heart of the acai for sale. Regarding uses: $38 \%$ use for medicinal purposes; $15 \%$ for fence construction on properties; and $8 \%$ as fertilizer. The most used parts of acai were root, stem (15\%) and seed (8\%). However, $62 \%$ reported not making any use of the by-products of the acai berry.

The use of acai fruit in the preparation of wine for the composition of the diet of the family of native acai owners is a fact, but it was necessary to identify the uses of the acai byproducts, parts used and the purpose. In ethnobotanical research in the lower Araguari River, Moraes et al. (2019) reported great potential for the use of forest species by extractivists for medicinal purposes, with indication for the treatment of many diseases. In this same riverside community, which existed on the banks of the Araguari River, Santos et al. (2015) reported that the acai berry was the species most used by the interviewed families $(86.6 \%)$, due to its multiple use: medicinal, wood for small rural buildings and food.

Currently, there is a certain productive diversification from the fruit of acai. In Brazil, the fruit pulp and derivatives market is more expressive, while in the international market, there is intense technological innovation and product creation (Nogueira et al, 2013).

\subsection{Activities Exercised by Owners}

Regarding the declared activities, the most outstanding were livestock (23\%); agriculture $(15 \%)$; fishing and agriculture / extractivism ( $8 \%)$. The existence of native acai palm tree in the region is relevant, however most areas are difficult to access and unmanaged. The absence of the State in rural extension actions and technical assistance to landowners poses a problem for the development of the acai berry economic activity in Araguari, influencing the practice of other productive activities, some unrelated to extractivism.

Carvalho (2018) emphasizes the importance of acai, in recent decades has been the most important forest, cultural and food species of the Amazonian floodplains. According to Santana (2003), acai's economic activity is a relevant generator of direct and indirect jobs in the state of Pará, being part of the food culture of millions of people in urban and rural areas.

\subsection{Fruit Trading Locations}

One of the main problems in the marketing of acai fruit is the correct adaptation of the places. Because they are familiar, they sell at their own port (8\%); at municipal headquarters (8\%); and both at home $(15 \%)$.

Despite the favorable local characteristics of the acai productive activity, such as presence of 
native acai massifs and proximity to the administrative headquarters of the municipalities of Ferreira Gomes and Cutias, $69 \%$ of the owners interviewed do not sell the acai fruit.

According to data from IBGE (2017), the national production of acai fruit was 219.885 tons, $2.0 \%$ higher than 2016. This increase resulted in a $10.5 \%$ growth in production value ( $\mathrm{R}$ \$ 596.8 million). Only in the state of Pará, in 2014 was estimated in 5.000 to 6.000 tons of exported fruits (Tavares \& Homma, 2015).

\subsection{Rural Credit and Extension}

State incentives are paramount for the growth and development of any economic activity, especially those that are eminently familiar and poorly assisted. When asked about state and municipal technical assistance, they reported that they were never assisted. About the knowledge of credit lines for acai activity and training for forest management of the species reported not knowing and have not done any course.

When asked about the commercial interest of inserting productive activity in their property, 92\% were favorable. Regarding the motivation to work with the acai tree on the property, $31 \%$ were encouraged by third parties, while $69 \%$ were not motivated.

All owners interviewed have dense acai palm tree areas with potential for commercial exploitation of the fruit, but this is not a sufficient factor to leverage productive activity, especially in the Araguari River Valley. Several factors combined must contribute to the economic success of the activity, which must be accessible to extractivists.

Lima et al. (2013) point out as obstacles the acai activity, the low training of extractivists and the incipient access to health services by the riverside families, which compromises the hygienic-sanitary quality of the fruit and value addition. The integration between state and municipal managers is a relevant factor for the exchange of information and joint planning for the effective promotion of acai economic activity in the Araguari River valley.

\section{Conclusion}

This field research with extractivists allows us to infer that the period of high fruit production extends from March to June. The fact that most owners of acai do not sell the fruit produced and the lack of basic silvicultural treatments for the forest management of the species are the main factors of disinterest in the activity of acai berry.

Acai palm tree is a species considered to be of multiple use in many places of occurrence, but in the Araguari River Valley, the use of acai berry byproducts is not expressive. Although cattle breeding is the most practiced activity in the region, there are other potential activities such as fishing, agriculture and extractivism, mainly acai.

The acai berry productive activity in the Araguari River Valley lacks the technical, banking, productive, economic and training incentives of producers. Continued disinterest in activity in the region may compromise family food security and induce the insertion of exogenous economic activities into riverine and regional characteristics. 


\section{Acknowledgements}

The Research Support Foundation of the state of Amapá (FAPEAP) for the financial support of the research project, process related to the Araguari Valley Research Incentive Program, Public Call 004/2017/FAPEAP and pursuant to Memo No. 003/2018-CCT/FAPEAP and Ferreira Gomes Energia S/A. The Instituto Estadual de Florestas do Amapá (IEF/AP) and Instituto de Desenvolvimento Rural do Amapá (RURAP) for their support. To the extractivist producers of the middle and lower Araguari River.

\section{References}

Alvares, C. A. et al. (2013). Köpen's climate classification map for Brazil. Meteorologische Zeitschrift, 22, 711-728. http://dx.doi.org/10.1127/0941-2948/2013/0507

Amsellem-Laufer, M. (2015). Euterpe oleracea Mart. (Arecaceae): Açaí. Phytothérapie, 13, 135-140. http://dx.doi.org/10.1007/s10298-015-0942-2.

Araujo, C. T. D., \& Navegante-Alves, L. F. (2015). Do extrativismo ao cultivo intensivo do açaizeiro (Euterpe oleracea Mart.) no estuário amazônico: sistemas de manejo e suas implicações sobre a diversidade de espécies arbóreas. Revista Brasileira de Agroecologia, 10, 12-23.

Bichara, C. M. G., \& Rogez, H. (2011). Açai (Euterpe oleracea Martius). Postharvest Biology and Technology of Tropical and Subtropical Fruits, 27, 1-26.

https://doi.org/10.1016/B978-0-12-803138-4.00002-2

Calzavara, B. B. G. (1972). As possibilidades do açaizeiro no estuário amazônico. Boletim da Faculdade de Ciências Agrárias do Pará - FCAP. Belém, (5), 103p.

Carvalho, R. C. (2018). Recuperação florestal em açaizais de várzea submetidos ao manejo intensivo no estuário amazônico. 2018. 105 f. Dissertação (mestrado) - Universidade Federal do Pará, Belém, 2018. http://repositorio.ufpa.br/

Chambers, R. (1994). Participatory rural appraisal (PRA): Analysis of experience. World development, 22(9), 1253-1268.

FAO. (2014). O Estado da Insegurança Alimentar no Mundo. Fortalecimento de um ambiente favorável para a segurança alimentar e nutrição. Roma, FAO.

FAO. (2018). Food and Agriculture Orgazation of The United Nations. The State of Food Security and Nutrition in the World 2018. Building climate resilience for food security and nutrition. Rome: FAO. 202p.

Fiedler, N. C., Soares, T. S., \& Silva, G. F. (2008). Produtos florestais não madeireiros e manejo sustentável da floresta. Paraná. Revista Ciências Exatas e Naturais, 10(2).

Freitas, J. L. (2001). Período de produção e importância econômica de açaizais nativos (Euterpe oleracea Mart.) para os extrativistas das várzeas do estuário amazônico: O caso de Gurupá. Amapá, Ciência e Tecnologia, 2(1), 52-60. 
Freitas, J. L., Cruz Junior, F. O., Santos, E. S., \& Santos, A. C. (2019). Avaliação do potencial de produção de fruto do açaizeiro nativo de várzea do vale do rio Araguari. Relatório Técnico de Pesquisa. Macapá, 49 p.

Freitas, J. L., Malheiros, M. A., \& Ohashi, S. T. (2006). Fenologia reprodutiva do açaizeiro (Euterpe oleracea Mart.) em três municípios do estuário amazônico. In: FRAZÃO, D. A. HOMMA, A. K., VIÉGAS, I. J. (Editores). Contribuição ao desenvolvimento da fruticultura da Amazônia. Embrapa Amazônia Oriental, Belém, Pará, Brasil. p.85-89.

Freitas, J. L., Santos M. M. L., \& Oliveira, F. A. (2010). Fenologia reprodutiva de espécies potenciais para arranjo em sistemas agroflorestais, na Ilha de Santana, Amapá. Revista de Ciências Agrárias, 53(1), 78-86.

Freitas, J. L., Silva, R. B. L., Cruz Junior, F. O., Cantuária, P. C., Medeiros, T. D. S., \& Santos, E. S. (2018). Composição florística arbórea em reserva extrativista no Amapá. Revista em Agronegócio $\quad$ Meio Ambiente, 277-300, 2018.http://dx.doi.org/10.17765/2176-9168.2018v11n1p277-300

Freitas, M. A. B., Vieira, I. C. G., Albernaz, A. L. K. M., \& Magalhães, J. L. L. (2015). Floristic impoverishment of Amazonian floodplain forests managed for açaí fruit production. Forest Ecology and Management, 351, 20-27.

http://dx.doi.org/10.1016/j.foreco.2015.05.0080378-1127/ 2015

Higman, S., Mayers, J., Bass, S., Judd, N., \& Nussbaum, R. (2015). Manual do Manejo Florestal Sustentável. Tradução $2^{\mathrm{a}}$ edição, Tradutora: Aurea Maria Brandi Nardelli. Universidade Federal de Viçosa.

IBGE. (2017). Instituto Brasileiro de Geografia e Estatística. Produção da extração vegetal e da silvicultura. IBGE, Rio de Janeiro, Brasil. https://agenciadenoticias.ibge.gov.br

ITTO. (1998). International Tropical Timber Organization. Produtos florestais não-madeireiros: processamento, coleta e comercialização. Relatório Técnico. Brasília, p. 54.

Lima, E. U., Homma, A. K. O., Tahim, E. F., Brienza Júnior, S., \& Tavares, F. B. (2015). O arranjo produtivo local (APL) do açaí na ilha de Arumanduba (Abaetetuba/PA): um estudo de caso na comunidade Nossa Senhora da Paz. In $51^{\circ}$ Congresso da SOBER - novas fronteiras da agropecuária no Brasil e na Amazônia: desafios da sustentabilidade. Belém - PA.

Mendes, A. M., Lopes, M. L. B., Falesi, L. A., \& Filgueiras, G. C. (2012). O mercado de açaí no estado do Pará: uma análise recente. Amazônia: Ci. \& Desenv., 8(15).

Moraes, L. L. C., Freitas, J. L., Matos Filho, J. R., Silva, R. B. L., Borgesc. H. A., \& Santos, A. C. (2019). Ethno-knowledge of medicinal plants in a community in the eastern Amazon. Revista de Ciências Agrárias, 42(2), 565-573. http://dx.doi.org/10.19084/rca.15625.

Neves, L. T. B. C., Campos, D. C. S., Mendes, J. K. S., Urnhani, C. O., \& Araújo, K. G. M. (2015). Qualidade de frutos processados artesanalmente de açaí (Euterpe oleracea Mart.) e bacaba (Oenocarpus bacaba Mart.). Revista Brasileira de Fruticultura, 37(3), 729-738. DOI:10.1590/0100-2945-148/14. 
Nogueira, A. K. M., Santana, A. C. D., \& Garcia, W. S. (2013). A dinâmica de mercado do açaí fruto no estado do Pará: 1994 a 2009. Revista Ceres, 60(3), 324-331.

Nogueira, O. L., \& Homma, A. K. (2014). Importância do manejo de recursos extrativos em aumentar a capacidade de suporte: o caso de açaizeiros (Euterpe oleraceae Mart.) no estuário amazônico. In: HOMMA, A. K. O. (Ed.). Extrativismo vegetal na Amazônia: história, ecologia, economia e domesticação. Brasília, DF: Embrapa. Cap. 10, 167-176.

Oliveira, M. S. P., \& Schwartz, G. (2018). Açaí - Euterpe oleracea. Exotic Fruits, 1-5. https://doi.org/10.1016/B978-0-12-803138-4.00002-2

Pinto, A., Amaral, P., Gaia, C., \& Oliveira, W. (2010). Boas práticas para manejo florestal e agroindustrial de produtos florestais não madeireiros: açaí, andiroba, babaçu, castanha-do-brasil, copaíba e unha-de-gato. Belém, PA: Imazon, Manaus, AM: Sebrae-AM. 180.

Quaresma, S. M., \& Cunha, E. B. (2012). Manejo de açaizais como prática de gestão e educação ambiental: um estudo de caso da comunidade de franco grande do Bailique/Amapá. Revista Meio Ambiente e Sustentabilidade, 2(1),

100-120.https://www.uninter.com/revistameioambiente

Queiroz, J. A. L., Mochiutti, S., \& Santos, J. A. S. (2015). Manejo de Açaizais de Grotas. Embrapa Amapá.

Santana, A. C. (2003). Mercados e comercialização de produtos do açaí. Belém: UFRA. 40.

Santos, A. C., Freitas, J. L., Silva, R. B. L., Moraes, L. L. C., Matos Filho, J. R., Cruz Junior, F. O., \& Cantuária, P. C. (2015). Caracterização da atividade extrativa vegetal na comunidade São Tomé, Ferreira Gomes, Amapá, Brasil. Biota Amazônia. Macapá, 5(4), 42-47.

Sardinha, M. A., Freitas, J. L., Santos, A. C., Cruz Junior, F. O., \& Santos, E. S. (2017). Florística e utilização de espécies florestais em assentamento agroextrativista, Amapá, Amazônia Oriental. Enciclopédia Biosfera, 14(26), 595-610. Disponível em: http://www.conhecer.org.br/enciclop/2017b/agrar.htm

Silva Junior, J. I. S., Rebello, F. K., Lima, H. V., Santos, M. A. S., Santos, P. C. S., \& Lopes, M. L. B. (2019). Socio-economics of Acai Production in Rural Communities in the Brazilian Amazon: A Case Study in the Municipality of Igarapé-Miri, State of Pará. Journal of Agricultural Science, 11(5), 215-224. DOI:10.5539/jas.11(5)215

Silva, N. B., Lopes, J. O., Brito, J. D. M., Santos, S. K., Takiyama, L. R., Montagner, A. E. A. D., \& Oliveira, E. D. C. (2018). Diagnóstico da qualidade da água em áreas utilizadas pela bubalinocultura no Baixo Araguari, Amapá, Brasil. Biota Amazônia, 8(1), 22-28. http://dx.doi.org/10.18561/2179-5746/biotaamazonia.v8n1p22-28.

Soares, T. S., Fiedler, N. C., Silva, J. A., \& Gasparini Júnior, A. J. (2008). Produtos florestais não madeireiros. Revista Científica Eletrônica de Engenharia Florestal. (11), 1-7.

Tavares, G. S., \& Homma, A. K. O. (2015). Comercialização do açaí no Estado do Pará: 


\section{Macrothink}

Journal of Agricultural Studies

ISSN 2166-0379 2020, Vol. 8, No. 2

alguns comentários. Revista Eumednet, 1-13.

https://ainfo.cnptia.embrapa.br/digital/bitstream/item/135458/1/acai-para.pdf

Tropicos. (2018). Euterpe oleracea Mart. Disponível em:

http://www.Trópicos.org/Name/2401358.

\section{Copyright Disclaimer}

Copyright for this article is retained by the author(s), with first publication rights granted to the journal.

This is an open-access article distributed under the terms and conditions of the Creative Commons Attribution license (http://creativecommons.org/licenses/by/4.0/). 